\title{
A rheumatoid arthritis okozta országos epidemiológiai és egészségbiztosítási betegségteher Magyarországon
}

\author{
Elmer Diána ${ }^{1,2}$ - Endrei Dóra dr., ${ }^{1,2}$ - Sebestyén Andor dr., ${ }^{1,2}$ \\ Csákvári Tímea ${ }^{2,3}$. Németh Noémi ${ }^{1,2}$ - Horváth Lilla ${ }^{1,2}$ - Pónusz Róbert ${ }^{1,2}$ \\ Kumánovics Gábor dr. ${ }^{4}$ - Boncz Imre dr. ${ }^{1,2}$ - Ágoston István dr. ${ }^{1,2}$ \\ ${ }^{1}$ Pécsi Tudományegyetem, Egészségtudományi Kar, Egészségbiztosítási Intézet, Pécs \\ ${ }^{2}$ Pécsi Tudományegyetem, Egészségtudományi Kar, \\ Real World \& Big Data Egészség-gazdaságtani Kutatóközpont, Pécs \\ ${ }^{3}$ Pécsi Tudományegyetem, Egészségtudományi Kar, Egészségbiztosítási Intézet, Zalaegerszeg \\ ${ }^{4}$ Pécsi Tudományegyetem, Általános Orvostudományi Kar, Klinikai Központ, \\ Reumatológiai és Immunológiai Klinika, Pécs
}

Bevezetés: A rheumatoid arthritisszel kapcsolatos szolgáltatások igénybevétele nagy teher az egészségügyi rendszerek számára.

Célkitüzés: Elemzésünk célja volt a rheumatoid arthritis okozta éves epidemiológiai és egészségbiztosítási betegségteher meghatározása Magyarországon.

Adatok és módszerek: Az elemzésben felhasznált adatok a Nemzeti Egészségbiztosítási Alapkezelő (NEAK) finanszírozási adatbázisából származnak, és a 2018. évet fedik le. Meghatároztuk az éves betegszámokat, a prevalenciát 100000 lakosra, továbbá az éves egészségbiztosítási kiadásokat korcsoportos és nemenkénti bontásban valamennyi egészségbiztosítási ellátás tekintetében. A rheumatoid arthritis kórképet fődiagnózisként a Betegségek Nemzetközi Osztályozása (BNO, 10. revízió) szerinti M0690-es kóddal azonosítottuk.

Eredmények: Meghatározó betegforgalmat a gyógyszerek ártámogatása esetében találtunk: 7015 férfi, 23696 nő, együtt 30711 fő. A gyógyszer-ártámogatás betegforgalmi adatai alapján a 100000 foóre eső prevalencia férfiaknál 150,2 fó, nóknél 464,0 fo, együtt 314,1 fő volt. A rheumatoid arthritis kezelésére a NEAK 1,64 milliárd Ft-ot (6,07 millió USD, illetve 5,14 millió EUR) költött 2018-ban. A kiadások 19,3\%-a férfiaknál, míg 80,7\%-a nőknél jelenik meg. A gyógyszer-ártámogatás (az összes kiadás 42,8\%-a), a járóbeteg-szakellátás (21,9\%) és az aktívfekvő́betegszakellátás $(12,4 \%)$ voltak a meghatározó költségelemek. Az egy betegre jutó átlagos éves egészségbiztosítási kiadás $53375 \mathrm{Ft}$ (198 USD/167 EUR) volt.

Következtetés: A gyógyszerek ártámogatása bizonyult a fó költségtényezőnek. A rheumatoid arthritis előfordulási gyakorisága 3,1-szer magasabb a nók esetében a férfiakhoz képest.

Orv Hetil. 2021; 162(Suppl 1): 30-37.

Kulcsszavak: rheumatoid arthritis, betegségteher, egészségpolitika, egészségbiztosítás, finanszírozás

\section{Nationwide epidemiological and health insurance disease burden of rheumatoid arthritis in Hungary}

Introduction: Utilisation of services related to the treatment of rheumatoid arthritis poses a great burden for healthcare systems.

Objecive: Our aim was to determine the annual epidemiological disease burden and the health insurance treatment cost of rheumatoid arthritis in Hungary.

Data and methods: Data were derived from the financial database of the National Health Insurance Fund Administration (NHIFA) of Hungary, for the year 2018. The data analysed included annual patient numbers and prevalence per 100000 population and annual health insurance treatment costs calculated for age groups and sex according to all health insurance treatment categories. Patients with rheumatoid arthritis were identified as main diagnosis with the following code of the International Classification of Diseases, 10th revision: M0690.

Results: We found a significant patient turnover in pharmaceutical reimbursement: 7015 men, 23696 women, in total 30711 patients. Based on patient numbers in pharmaceuticals, prevalence for 100000 population among men was 150.2 patients, among women 464.0, in total 314.1 patients. In 2018, NHIFA spent 1.64 billion HUF 
(6.07 million USD, 5.14 million EUR) on the treatment of patients with rheumatoid arthritis. 19.3\% of the costs was spent on the treatment of male, $80.7 \%$ on female patients. Pharmaceuticals ( $42.8 \%$ of the total expenditures), outpatient care $(21.9 \%)$ and acute inpatient care $(12.4 \%)$ were the main cost drivers. Average annual health insurance treatment cost per patient was 53375 HUF (198 USD/167 EUR).

Conclusion: Pharmaceutical reimbursement was the major cost driver. The prevalence of rheumatoid arthritis was by 3.1 higher in women compared to men.

Keywords: rheumatoid arthritis, disease burden, health policy, health insurance, financing

Elmer D, Endrei D, Sebestyén A, Csákvári T, Németh N, Horváth L, Pónusz R, Kumánovics G, Boncz I, Ágoston I. [Nationwide epidemiological and health insurance disease burden of rheumatoid arthritis in Hungary]. Orv Hetil. $2021 ; 162$ (Suppl 1): 30-37.

(Beérkezett: 2021. január 3.; elfogadva: 2021. január 24.)

\begin{abstract}
Rövidítések
BNO = Betegségek Nemzetközi Osztályozása CT = $($ comput ed tomography) komputertomográfia; DMARD = (diseasemodifying antirheumatic drug) betegségmódosító reumaellenes gyógyszer; EFOP = Emberi Erőforrás Fejlesztési Operatív Program; GYÓGYINFOK = Gyógyító Ellátás Információs Központ; MRI = (magnetic resonance imaging) mágnesesrezonancia-képalkotás; NEAK = Nemzeti Egészségbiztosítási Alapkezelő; OEP = Országos Egészségbiztosítási Pénztár; PET $=$ pozitronemissziós tomográfia
\end{abstract}

A rheumatoid arthritis krónikus, szisztémás gyulladásos autoimmun megbetegedés, mely progresszív ízületi károsodással és fogyatékossággal társulhat. Az egyén aktivitását, munkaképességét negatívan befolyásolhatja, ami nemcsak az egyén, hanem az egészségügyi rendszer szempontjából is releváns tényező. A kórkép epidemiológiája, genetikája, etiológiája, patofiziológiája és diagnosztikája, valamint terápiás lehetőségei már részletesen ismertetésre kerültek korábbi tanulmányokban [1-4]. A krónikus megbetegedésekkel összefüggő szolgáltatások megnövekedett igénye nagy terhet jelent az egészségügyi rendszerek számára [5].

A betegség előfordulása földrajzi régiónként változó. Alamanos és mtsai szisztematikus irodalomelemzése alapján elmondható, hogy a rheumatoid arthritis éves incidenciájának mediánja Észak-Amerikában 38/100 000 fó, Észak-Európában 29/100 000 fó, míg Dél-Európában 16,5/100 000 före tehető. A kórkép éves prevalenciájának mediánja Észak-Amerikában 10,7/1000 före, Észak-Európában 5,0/1000 före, míg Dél-Európában $3,3 / 1000$ före becsülhető [6].

Batko és mtsai szakirodalmi adatgyưjitése és kutatása szerint Európában Franciaországban 0,31\%, Olaszországban 0,33\%, Finnországban 0,8\%, Angliában 0,85\% és Lengyelországban $0,9 \%$ a rheumatoid arthritis előfordulási gyakorisága [7].

Elemzések támasztják alá, hogy a rheumatoid arthritis prevalenciája és incidenciája globálisan nő, és a legtöbb beteg az idősebb korcsoportokban található; a nők körében gyakrabban fordul elö $[8,9]$.
A rheumatoid arthritis jelentős gazdasági terhét több tanulmány is kiemelte. A betegségköltségek gazdasági hatásait - a jelen esetben a rheumatoid arthritisét is - direkt (például gyógyszerköltség, kezelési költség, kórházi ellátási költség), indirekt (például termelékenységi csökkenés munkahelyi távollét miatt) és immateriális költségeken keresztül számszerűsíthetjük, ugyanakkor az immateriális költségeket gyakran kihagyják a gazdasági tanulmányokból, mert nehéz mérni $[10,11]$.

Az orvosi költségek mértékét a választott gyógyszeres terápia is befolyásolja [12]. Azokban az esetekben, amelyekben az ún. szintetikus betegségmódosító reumaellenes gyógyszerre (DMARD) épülő terápiák nem elég hatásosak a betegség aktivitását illetően, az azoknál sokkal költségesebb biológiai DMARD-ra épülőket részesítik előnyben $[13,14]$ - ezeknél ugyancsak fennáll a terápia hatástalanságának, nem kívánt mellékhatásának vagy egyéb tényező miatti megszakításának veszélye, illetve a más biológiai terápiára való áttérés esélye [15].

A rheumatoid arthritis kezelésének magas költségterhét több tanulmány is vizsgálta: Európában 45,3 milliárd EUR-ra, az Amerikai Egyesült Államokban 41,6 milliárd EUR-ra becsülték a betegséggel összefüggésbe hozható költségeket társadalmi szinten [16]. Egy egyesült államokbeli tanulmány szerint az egy betegre jutó átlagos éves direkt egészségügyi költség 2001-ben 9519 USD volt. A gyógyszerköltség az összkiadások 66\%-át (6324 USD) tette ki, a hospitalizációs költségek pedig csak 17\%-ot (1573 USD) [12]. Franciaországban az egy betegre jutó átlagos éves direkt költség 4003 EUR volt, amelyen belül a hospitalizációs költségek jelentették a legmeghatározóbb költségelemet (60\%) [17]. Svédországban egy 20 évet felölelő egészség-gazdaságtani elemzés alapján elmondható, hogy a rheumatoid arthritis kezelésére 1990-ben - a 2010. évi fogyasztói árindexszel korrigálva - 454 millió EUR-t, majd 2010-ben már összesen 600 millió EUR-t fordítottak, ami leginkább a gyógyszerárak jelentős növekedése miatt következett be [18]. Egy törökországi tanulmány az egy betegre jutó átlagos éves direkt egészségügyi költségeket 4954 EURban határozta meg, amelyből a gyógyszerköltség (2777 
EUR) volt a legnagyobb tétel [19]. Görögországban 2014. június és 2015. június között egy tanulmányban az összes térített gyógyszerköltség 81206 363,70 EUR volt, amelyből 52732 142,18 EUR-t (65\%) a biológiai terápiák költsége tett ki. Az egy före jutó átlagos éves kezelési költség pedig 2263,72 EUR volt [20].

Elemzésünk célja volt a rheumatoid arthritis okozta éves, országos szintû epidemiológiai és egészségbiztosítási betegségteher meghatározása Magyarországon a 2018-as évben.

\section{Adatok és módszerek}

Az elemzésben felhasznált adatok a Nemzeti Egészségbiztosítási Alapkezelő (NEAK) finanszírozási adatbázisából származnak, és a 2018. évet fedik le. Az elemzéshez bevont rheumatoid arthritises betegkört a Betegségek Nemzetközi Osztályozása (BNO, 10. revízió) szerinti „M0690 Rheumatoid arthritis k.m.n.” kóddal azonosítottuk.

A lekérdezés során az alábbi egészségbiztosítási ellátások kerültek bevonásra: háziorvosi ellátás; otthoni szakápolás; járó- és fekvőbeteg-szakellátás; képalkotó diagnosztika (komputertomográfia [CT], mágnesesrezonancia-képalkotás [MRI], pozitronemissziós tomográfia [PET]) és laboratóriumi ellátás; gondozóintézeti gondozás; tételes elszámolás alá eső egyszer használatos eszközök, implantátumok, gyógyszerek és nagy értékú mútéti eljárások; gyógyszer- és gyógyászatisegédeszközártámogatás; betegszállítás és mentés.

Az aktív- (benne a kúraszerú és az egynapos) és a krónikusfekvőbeteg-szakellátások esetében az adatlekérés során a NEAK kórházi (osztályos) ápolási esetről szóló adatlapjának 26. mezőjében található diagnózisok közül a következőket kérdeztük le: „l. ápolást indokló fódiagnózis alapjául szolgáló betegség”, illetve „3. ápolást indokló fódiagnózis”. Az elemzések során az aktív- és a krónikus-szakellátások adatai közül a „3. ápolást indokló fődiagnózis" tétel adatait elemeztük. A járóbeteg-szakellátásnál (laboratóriumi ellátás és gondozóintézeti gondozás nélkül) a BNO-t az ambuláns adatlap 26. mezőjében található diagnózisok közül az 1. helyen szereplő diagnózis képezte. A laboratóriumi ellátás során az ambuláns adatlap 26. mezőjében található diagnózisok közül pedig az 1 . helyen szereplő diagnózis jelentette a BNO-t. A CT-k, MRI-k esetében az adatlap 17. mezőjében található „Vizsgálat utáni diagnózis” BNO-kódját vettük figyelembe. A gondozóintézeti gondozás ellátási formánál az ambuláns adatlap 26. mezőjében található diagnózisok közül az 1 . helyen szereplő diagnózist használtuk. Az otthoni szakápolás tekintetében az alapbetegség-BNO-t, a betegszállításban az adatlap 21. mezőjében található szállítás indokául szolgáló BNO-t, a mentés esetében a 6. mezőben található „a mentés indokául szolgáló diagnózis”-t, míg a háziorvosi ellátásban az ellátás oka diagnózis BNO-kódját kértük le. A tételes elszámolás alá eső egyszer használatos eszközöket, implantátumokat, gyógyszereket és nagy értékű mütéti eljárásokat az adatlap 16. mezőjében található „az eszköz felhasználását/az elvégzett beavatkozást indikáló diagnózis" BNO-kódja szerint, míg a tételes elszámolású gyógyszereket az adatlap 11. mezőjében található „a beavatkozást/kezelést indikáló diagnózis” BNO-kódja szerint kérdeztük le.

A NEAK egyedi adatokból aggregált adatokat szolgáltatott számunkra a NEAK adatvédelmi szabályainak

1. táblázat |Az éves betegszám és az egészségbiztosítási kiadások alakulása a rheumatoid arthritisben szenvedők körében ellátási formánként (NEAK, 2018)

\begin{tabular}{|c|c|c|c|c|c|c|}
\hline \multirow{2}{*}{$\begin{array}{l}\text { Ellátási forma } \\
\text { (NEAK-kassza) }\end{array}$} & \multicolumn{3}{|c|}{ Betegszám (fö) } & \multicolumn{3}{|c|}{ NEAK-finanszírozás (Ft) } \\
\hline & Férfi & Nő & Együtt & Férfi & Nő & Együtt \\
\hline Háziorvosi ellátás & 8075 & 27282 & 35357 & 22301999 & 86065481 & 108367480 \\
\hline Otthoni szakápolás & 26 & 173 & 199 & 1647536 & 12862421 & 14509957 \\
\hline Betegszállítás & 99 & 469 & 568 & 3948693 & 21048890 & 24997583 \\
\hline Mentés & 8 & 9 & 17 & - & - & - \\
\hline Járóbeteg-szakellátás & 5729 & 24122 & 29851 & 60052324 & 299326057 & 359378381 \\
\hline Gondozóintézeti gondozás & 81 & 371 & 452 & 764312 & 3311464 & 4075776 \\
\hline Laboratóriumi ellátás & 1655 & 6847 & 8502 & 8537711 & 39226428 & 47764139 \\
\hline CT, MRI & 102 & 459 & 561 & 3283745 & 15217404 & 18501149 \\
\hline PET & 0 & 0 & 0 & 0 & 0 & 0 \\
\hline Aktívfekvőbeteg-szakellátás & 170 & 869 & 1039 & 34020378 & 169955655 & 203976033 \\
\hline Krónikusfekvőbeteg-szakellátás & 87 & 552 & 639 & 13757238 & 93564042 & 107321280 \\
\hline Tételes elszámolás & 0 & 0 & 0 & 0 & 0 & 0 \\
\hline Gyógyszer-ártámogatás & 7015 & 23696 & 30711 & 160021080 & 541344676 & 701365756 \\
\hline Gyógyászati segédeszközök ártámogatása & 119 & 745 & 864 & 8387585 & 40569541 & 48957126 \\
\hline Összesen & - & - & - & 316722602 & 1322492058 & 1639214660 \\
\hline
\end{tabular}

$\mathrm{CT}$ = komputertomográfia; MRI = mágnesesrezonancia-képalkotás; NEAK = Nemzeti Egészségbiztosítási Alapkezelő, PET = pozitronemissziós tomográfia 
megfelelően. Etikai jóváhagyás a jelen kutatáshoz nem volt szükséges.

$\mathrm{Az}$ epidemiológiai betegségteher vizsgálata során - első lépésként - meghatároztuk az éves betegszámokat és a 100000 lakosra jutó igénybevételi prevalenciát korcsoportos és nemenkénti bontásban. Az éves betegszám és a 100000 före eső prevalencia kiszámításához is a gyógyszer-ártámogatásnál bejelentett adatokat vettük figyelembe az egyes kasszák közötti duplikáció elkerülése végett, figyelembe véve, hogy a rheumatoid arthritisben szenvedő, diagnosztizált betegek gyógyszeres terápiában részesülnek. A prevalencia kiszámításakor a Központi Statisztikai Hivatalnak a magyarországi lakónépességre vonatkozó 2018. évi adatbázisát vettük alapul. Az egészségbiztosítási betegségteher vizsgálata során pedig meghatároztuk az egészségbiztosítási kiadásokat és a költségek megoszlását korcsoportos és nemenkénti bontásban. A teljes egészségbiztosítási kiadást és az egy főre eső egészségbiztosítási kiadásokat USD-ban (270,25 Ft/ USD) és EUR-ban $(318,87 \mathrm{Ft} / \mathrm{EUR})$ is a Magyar Nemzeti Bank 2018. évi éves átlagárfolyamán adtuk meg. A mentés esetében költségadatok nem álltak rendelkezésünkre. A PET, illetve a tételes elszámolás alá eső egyszer használatos eszközök, implantátumok, gyógyszerek és nagy értékű mútéti eljárások ellátási formák esetében nem jelentettek be adatokat (1. táblázat).

A magyar egészségügyi rendszer felépítésének, múködésének és finanszírozásának részletes leírása máshol megtalálható [21-27].

\section{Eredmények}

A rheumatoid arthritishez tartozó éves betegszámokat és egészségbiztosítási költségeket az 1. táblázat összegzi ellátási formánként/kasszánként. A legnagyobb orszá- gos betegszámot az ellátási forma szerint a 2018-as évben a háziorvosi ellátás esetében találtuk: 8075 férfi, 27282 nő, együtt 35357 fó. Ezt követte a gyógyszerártámogatásban (7015 férfi és 23696 nő, együtt 30711 fö), a járóbeteg-szakellátás igénybevételében ( 5729 férfi, 24122 nő, együtt 29851 fő), majd a laboratóriumi ellátásban (1655 férfi, 6847 nő, együtt 8502) található magas betegszám. A többi ellátási forma esetében jóval alacsonyabb volt a betegek száma.

A betegek nemek közti megoszlását nézve a legnagyobb betegforgalmú ellátási formákban azt tapasztaltuk, hogy egységesen jelentősen kevesebb volt a férfi betegek aránya: a háziorvosi ellátásban 22,8\% férfi és 77,2\% nő, a gyógyszer-ártámogatás igénybevételében szintén $22,8 \%$ férfi és 77,2\% nő, a járóbeteg-szakellátásban 19,2\% férfi és 80,8\% nő, míg a laboratóriumi ellátásban 19,5\% férfi és 80,5\% nő volt a megoszlási arány.

A gyógyszer-ártámogatás kor és nem szerinti igénybevételének vizsgálatakor azt tapasztaltuk, hogy a kor előrehaladtával mindkét nem esetében jelentősen nőtt a betegek száma. A gyógyszer-ártámogatás esetében 100000 lakosra nézve a legfiatalabb (0-24 év) korcsoportban összesen a nóknél 17,6 beteget, a 25-34 éves korcsoportban 95,6 föt, a 35-44 éveseknél 219,7 föt, a 45-54 éveseknél 486,9 föt, az 55-64 éveseknél 868,7 föt, a 65-74 éveseknél 1101,8 föt, míg a 75 év felettiek esetében 936,5 fö́t jelentettek be. A férfiaknál a 100000 lakosra jutó betegadat mérsékeltebb számokat mutatott az egyes korcsoportokban: 9,3 fó, 35,5 fó, 68,8 fó, 159,3 fó, 307,8 fó, 434,6 fó, 497,2 fö. A korcsoportos elemzés alapján megállapítható, hogy mindkét nem esetében 45 év felett kezdett emelkedni a betegszám (1. ábra).

Megállapítottuk továbbá a gyógyszer-ártámogatás betegforgalmi adatai alapján, hogy a 100000 före eső, valamennyi életkorra számított rheumatoid arthritis preva-

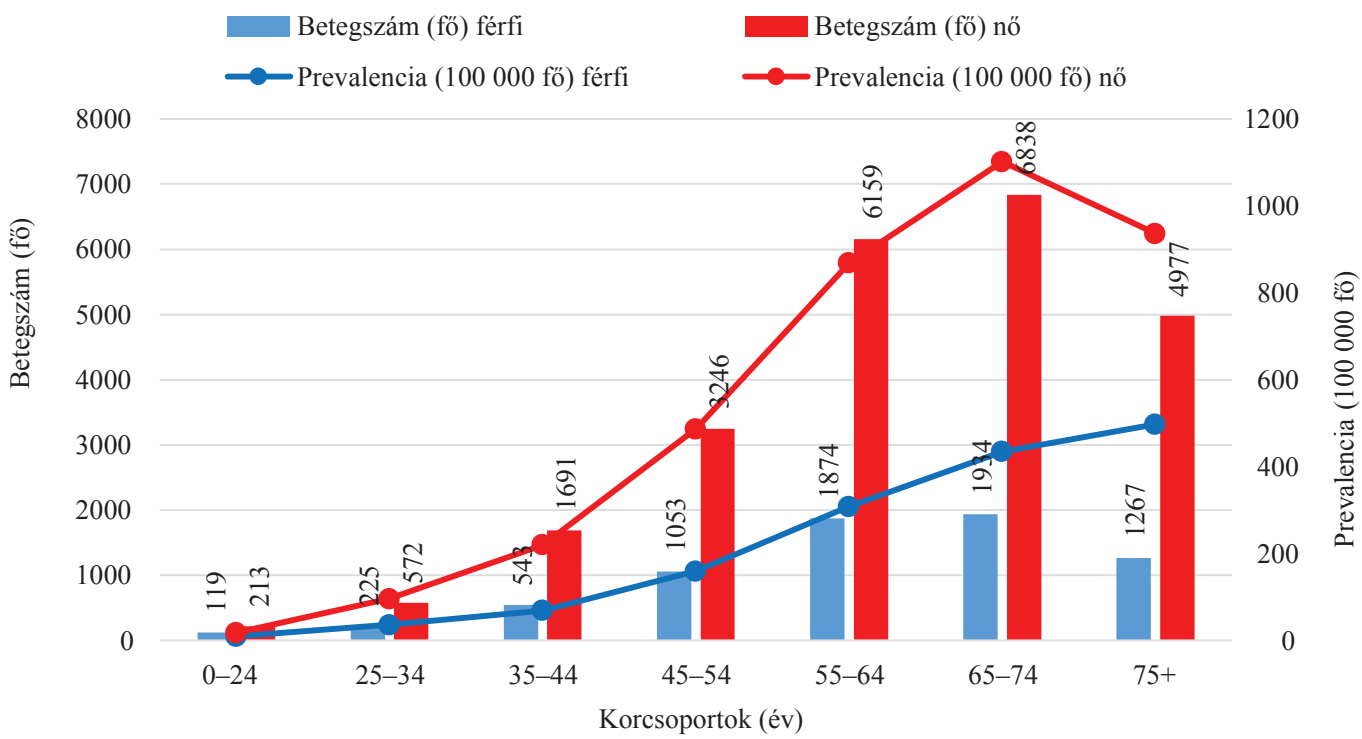

\begin{tabular}{l|l} 
1. ábra & $\begin{array}{l}\text { A rheumatoid arthritis becsült prevalenciája a gyógyszer-ártámogatás igénybevételének alapján kor és nem szerinti bontásban (NEAK, 2018) } \\
\text { NEAK = Nemzeti Egészségbiztosítási Alapkezelő }\end{array}$
\end{tabular} 


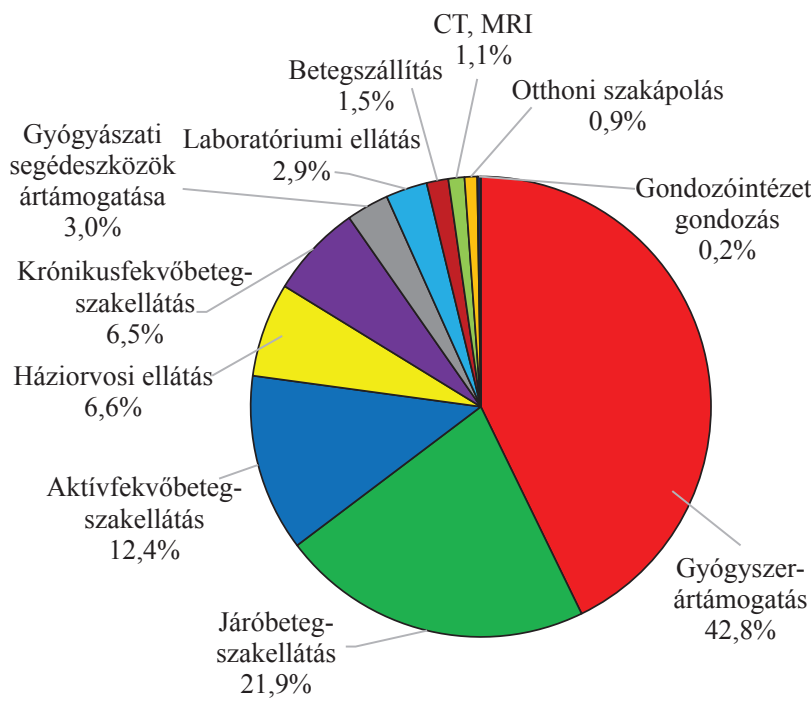

2. ábra

$$
\begin{aligned}
& \text { A rheumatoid arthritishez köthető éves egészségbiztosítási ke- } \\
& \text { zelési költségek megoszlása a NEAK-kasszákban (NEAK, 2018) } \\
& \text { CT = komputertomográfia; MRI = mágnesesrezonancia-képal- } \\
& \text { kotás; NEAK = Nemzeti Egészségbiztosítási Alapkezelő }
\end{aligned}
$$

lencia férfiaknál 150,2 fó, nóknél 464,0 fơ, együtt 314,1 fó volt Magyarországon 2018-ban.

A rheumatoid arthritis kezelésére a NEAK 1,64 milliárd Ft-ot költött 2018-ban, ami 6,07 millió USD-nak, illetve 5,14 millió EUR-nak felel meg. A NEAK különböző kiadási tételei az ellátási formák között erősen változnak. A legnagyobb tételt a kórkép esetében - sorrendben haladva - a gyógyszerkasszánál (701 365756 Ft; 42,8\%), a járóbeteg-kasszánál (359 $378 \quad 381$ Ft; 21,9\%), az aktívfekvőbeteg-kasszánál (203976 033 Ft;
12,4\%) és a háziorvosi kasszánál (108 367480 Ft; 6,6\%) találtuk (2. ábra).

A kiadások nemek közti megoszlását nézve a legnagyobb kiadású ellátási formákon belül azt tapasztaltuk, hogy a költségek a következő arányokban oszlottak meg: gyógyszer-ártámogatás: $22,8 \%$ férfi és $77,2 \%$ nő; járóbeteg-szakellátás: 16,7\% férfi és 83,3\% nő; aktívfekvőbetegszakellátás: szintén $16,7 \%$ férfi és $83,3 \%$ nő; háziorvosi ellátás: 20,6\% férfi és 79,4\% nő. Megállapítottuk, hogy a kiadások 19,3\%-a férfiaknál, míg 80,7\%-a nőknél jelent meg.

A NEAK összkiadásait nézve azt tapasztaltuk, hogy a gyógyszer-ártámogatás (a teljes egészségbiztosítási kiadás 50,5\%-a férfiaknál és 40,9\%-a nóknél), a járóbetegszakellátás (19,0\% férfiaknál és 22,6\% nőknél), az aktívfekvőbeteg-szakellátás $(10,7 \%$ férfiaknál és $12,9 \%$ nőknél), valamint a háziorvosi ellátás $(7,0 \%$ férfiaknál és 6,5\% nőknél) voltak a meghatározó költségelemek, míg az összes többi egészségügyi ellátási forma részesedése a férfiaknál $12,7 \%$, a nőknél 17,1\% volt.

A legnagyobb költségû gyógyszerkassza kor és nem szerinti igénybevételének vizsgálatakor azt láttuk, hogy a nők esetében jelentősen emelkedett az összkiadások mértéke a kor előrehaladtával, míg a férfiak esetében mérsékeltebb volt ez a növekedés. A férfiaknál kiemelkedik a 0-24 éves és az 55-74 éves korosztály. A gyógyszerkasszán belül hasonló tendencia látszik, mint a betegszám esetében: mindkét nem vonatkozásában a 45 év feletti korosztályok terhelték meg a leginkább a gyógyszerkasszát.

Megállapítottuk továbbá, hogy a NEAK az összkiadásai 75\%-át (1 $231476502 \mathrm{Ft}$ ) az 55 év feletti korosztály-

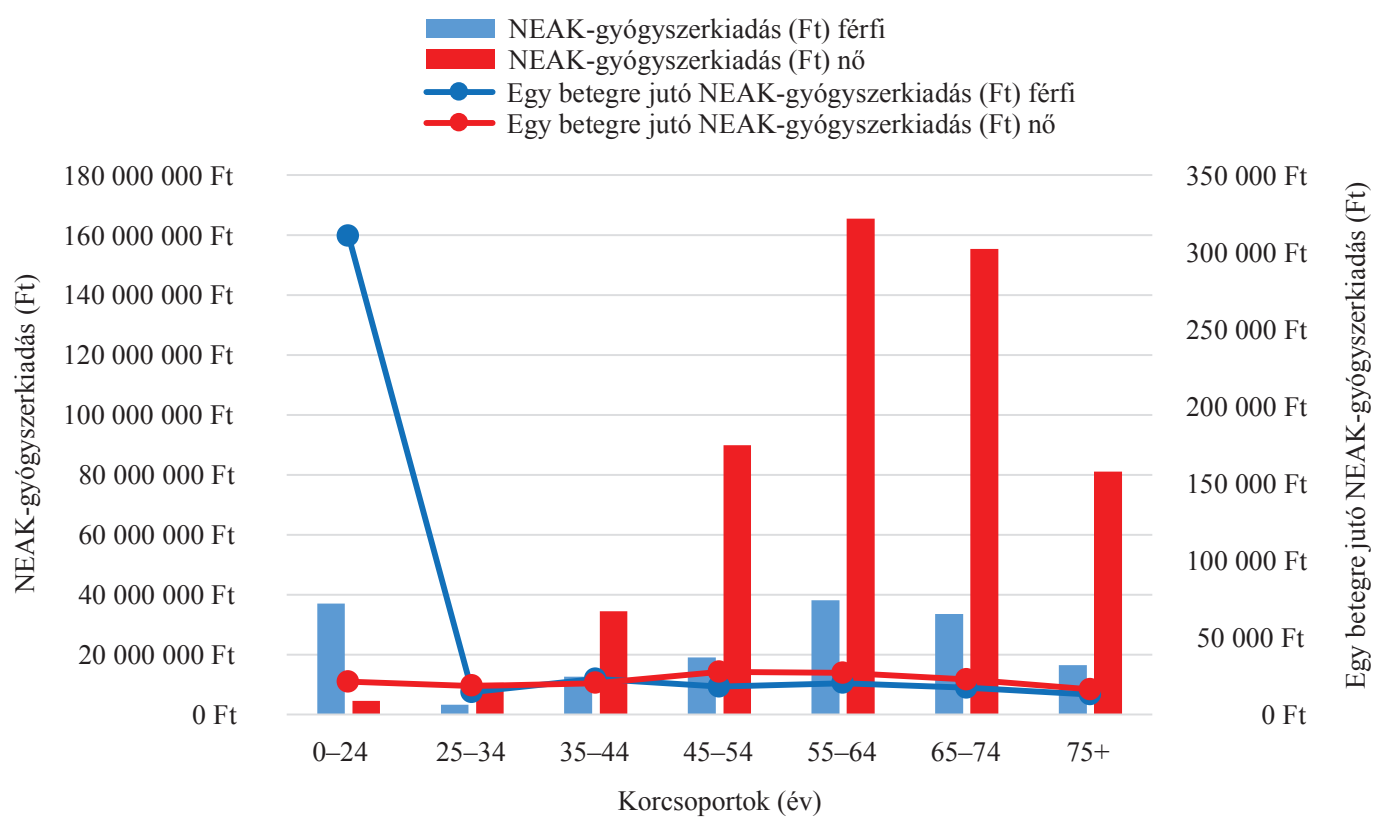

3. ábra

A rheumatoid arthritishez köthető gyógyszer-ártámogatás éves egészségbiztosítási költségeinek alakulása kor és nem szerinti bontásban (NEAK, 2018) NEAK = Nemzeti Egészségbiztosítási Alapkezelő 
ra, 46\%-át (757 $836321 \mathrm{Ft})$ a 65 év feletti korosztályra, 16\%-át (266 $998067 \mathrm{Ft})$ pedig a 75 év feletti korosztályra költötte.

Végül összegeztük, hogy 2018-ban a rheumatoid arthritisben szenvedő egy betegre jutó átlagos éves egészségbiztosítási kiadás a gyógyszer-ártámogatás alapján 53375 Ft (198 USD/l67 EUR) volt összesen; a férfiak esetében 45149 Ft (167 USD/142 EUR), a nők esetében pedig $55811 \mathrm{Ft}$ (207 USD/175 EUR) volt. A gyógyszer-ártámogatáson belül kiemelkedő volt a legfiatalabb korosztály a férfiak körében, ugyanis a 310599 Ft átlagos éves, egy főre jutó egészségbiztosítási kiadás a többi csoporthoz viszonyítva jelentős eltérést mutat (3. ábra).

\section{Megbeszélés}

Tanulmányunkban az M0690-es BNO-kóddal összefüggő „Rheumatoid arthritis k.m.n.” okozta, országos szintû epidemiológiai és egészségbiztosítási betegségteher vizsgálatát végeztük el a 2018-as évre vonatkozólag. Az elemzésben vizsgált betegség magyarországi prevalenciája 100000 fóre - a gyógyszer-ártámogatás alapján 150,2 fó volt a férfiaknál, 464,0 fö a nóknél, együtt 314,1 fó. Megállapítottuk, hogy a NEAK a 2018. évben 1,64 milliárd Ft-ot költött a betegség kezelésére, ami 6,07 millió USD-nak, illetve 5,14 millió EUR-nak felel meg.

A gyógyszer-ártámogatás és a háziorvosi ellátás vonatkozásában jelentett betegszámok azt mutatták, hogy megközelítőleg 5000 beteg nem jelent meg szakorvosnál, ami a kórkép esetében alapvető kritérium lenne. A betegszámoknál megfigyelt további aránytalanság, hogy a gyógyszerkassza betegszámához (30 711) képest nagyságrendekkel kevesebb (8502) beteg került bejelentésre a laboratóriumi ellátásnál. Tekintettel arra, hogy a kórkép monitorozásához és a (szintetikus, biológiai) DMARD-ra épülő terápiák mellékhatásainak követéséhez rendszeres laborvizsgálatok szükségesek, azt feltételezzük, hogy a laborvizsgálaton átesett 8502 beteg jelentôs részét az arthritiscentrumokba járó és biológiai terápiában részesülő betegek teszik ki, amelyeknél szigorú követelmény a rendszeres laborkontroll. 2014 decemberében 4464 rheumatoid arthritises beteg kapott biológiai terápiát, akiknek a száma azóta vélhetően tovább emelkedett [28]. Ebből arra lehet következtetni, hogy a 30711 , gyógyszert szedő beteg jelentős része vagy nem kap szintetikus DMARD-ot (például csak nemszteroid vagy szteroid gyulladáscsökkentőt kap), vagy laborkontroll nélkül szedi ezeket a DMARD-okat.

A kiadások nagy része $(80,7 \%)$ a nőknél jelent meg, és a gyógyszer-ártámogatás bizonyult a legmeghatározóbb költségelemnek. Az egy betegre jutó átlagos éves egészségbiztosítási kiadás a gyógyszer-ártámogatás alapján 53375 Ft (198 USD/167 EUR) volt. Az átlagos gyógyszerköltségek értelmezésekor fontos figyelembe venni, hogy 2006 óta a társadalombiztosítási finanszírozás mellett bevezetett biológiai DMARD-ok magas gyógyszerköltsége aránytalanul koncentrálódik a betegek körében. A 0-24 éves férfiak körében igen magas, 36961287 Ft volt a gyógyszerek ártámogatására kifizetett összeg - így az egy betegre jutó társadalombiztosítási támogatás a 0-24 éves férfiak körében 310599 Ft, ami nagyságrendileg magasabb, mint a többi korosztály egy före jutó társadalombiztosítási támogatása (12 931-27 657 Ft/fö). Ennek oka, hogy ebben a korosztályban kevesebb mint 10 férfi 2018-ban egyedi méltányosság jogcímén közel 36 millió Ft értékü készítményt váltott ki, ami jelentősen megemelte az egy fơre jutó korosztályos kiadásokat.

Nemzetközi összehasonlításban elmondhatjuk, hogy a magyar lakosság körében becsült rheumatoid arthritis prevalencia $(0,31 \%)$ nagyságrendileg Batko és mtsai [7] szakirodalmi kutatásaiban talált olaszországi $(0,33 \%)$ és franciaországi $(0,31 \%)$ prevalenciákhoz hasonlítható.

A gyógyszerkassza alapján megállapítottuk, hogy mindkét nem esetében 45 év felett kezdett emelkedni a betegszám, és a nők körében nagyobb $(3,09)$ a betegség előfordulási aránya, így hasonló megállapításra jutottunk, mint több más tanulmány $[6,8,9]$.

A közép-kelet-európai régióról - így Magyarországról is - nagyon korlátozottan állnak rendelkezésre epidemiológiai és költségadatok a rheumatoid arthritis vonatkozásában [29-32]. Kutatásunk az első olyan országos szintû́ elemzés, amely a társadalmi és a gazdasági teher oldaláról is megvizsgálja a rheumatoid arthritis kórképet valamennyi egészségbiztosítási kassza tekintetében, kor és nem szerinti bontásban.

Társadalmi oldalról az egykori Országos Egészségbiztosítási Pénztár (OEP) Gyógyító Ellátás Információs Központjának (GYÓGYINFOK) adatbázisából készült kutatás $0,5 \%$-os rheumatoid arthritis prevalenciát határozott meg. A tanulmány szerint a járóbeteg-szakellátás alapján 1999-ben 30996 fó, míg 2000-ben 30841 fó volt az M05-M06-os kódokon bejelentett rheumatoid arthritises betegek száma Magyarországon [33]. Egy másik hazai elemzés az OEP adatbázisából a 2004. évre a járó- és fekvőbeteg-szakellátás tekintetében 34312 , rheumatoid arthritisben szenvedő beteget azonosított (csak a járóbeteg-szakellátásban 29088 föt, a járó- és fekvőbeteg-szakellátásban 3990 föt, csak a fekvőbetegszakellátásban 1234 fót). A legmagasabb prevalenciát az 50-59 éves korcsoportban találták [34].

Az OEP adatbázisát érintő elemzéseken felül egy további, 2002-ben végzett reprezentatív tanulmány is rendelkezésünkre áll, amely hazánk dél-dunántúli régiójában vizsgálta a rheumatoid arthritis prevalenciáját a 14-65 éves korosztály esetében 10000 före vetítve. A kérdőíven és klinikai vizsgálaton alapuló felmérésük szerint az előfordulási gyakoriság 0,23\% volt a férfiaknál, $0,48 \%$ a nőknél, együtt $0,37 \%$ [35], amihez részben hasonló (férfiak: $0,15 \%$, nók: $0,46 \%$, együtt: $0,31 \%$ ) eredményeket kaptunk mi is az országos felmérés során. 
Az egészségbiztosítási költségteher tekintetében hazánkban egy 2004-ben készített tanulmány a rheumatoid arthritis esetében 4173 EUR-t (1,04 millió Ft) határozott meg egy betegre jutó átlagos éves költségként. A tanulmányban megállapították továbbá, hogy a rheumatoid arthritisben szenvedő betegek átlagos éves költsége egy betegre nézve szoros összefüggést mutatott a betegek funkcionális állapotában bekövetkezett romlással, progresszióval, és folyamatosan nőtt (628 2801371674 Ft) $[36,37]$. Más, reumatológiai és bőrgyógyászai kórképek hazai költségteher-vizsgálatainak vonatkozásában szisztémás sclerosisnál 9619 EUR [38], arthritis psoriaticánál 5574 EUR [39], psoriasisnál 9254 EUR [40] és 6,45 millió EUR [41], arthritis psoriaticával társuló psoriasisnál pedig 2559015 Ft (8842 EUR) volt az egy betegre jutó átlagos éves költség [42].

A költségteherrel kapcsolatos eredményeink vonatkozásában elmondható, hogy az egy betegre jutó átlagos éves költség (167 EUR) például Souliotis és mtsai görög tanulmányában található, egy betegre jutó átlagos éves DMARD-költséghez hasonlítható (154,14 EUR) [20]. A férfiak körében pedig a legfiatalabb korcsoportban kapott, 310599 Ft-os, egy betegre jutó átlagos éves gyógyszerköltség (1149 USD/974 EUR) a Michaud és mtsai amerikai tanulmányában meghatározott járóbetegszakellátási költségekhez (1541 USD) és a hospitalizációs költségekhez (1573 USD) mérhető nagyságrendileg [12].

A rheumatoid arthritis kezelésében nemzetközi és hazai szakmai irányelv is rendelkezésre áll $[43,44]$. A hazai irányelv átfogó elvei között szerepel, hogy „a rheumatoid arthritis a munkából való kiesés, a rokkantság és a korai nyugdíjazás miatt komoly indirekt költségveszteséget jelent az egyénnek, a családnak és a társadalomnak. A krónikus betegség direkt orvosi költségei is extrém magasak."

Elemzésünk korlátai közül kiemelendő a NEAK-adatbázishoz kapcsoló adatvaliditás és adatteljesség kérdése $[45,46]$, valamint az adatgyújtésben levő torzítások [47], amelyek nem haladják meg a nagy adatbázisok szokásos torzításait. Ugyanakkor fontos megjegyezni, hogy a NEAK-adatokon kívül jelenleg nem áll rendelkezésre más, országos szintú alternatív adatbázis - például rheumatoid arthritis regiszter -, amelynek elemzése pontosabb és részletesebb képet adhatna számunkra.

Tanulmányunk kiegészítéseként javasolt a későbbiekben országos elemzést készíteni azon BNO-k vonatkozásában is, amelyeknél a rheumatoid arthritis nemcsak födiagnózisként, hanem kísérő betegségként vagy szövődményként is szerepel.

Országos szintű vizsgálatunk a rheumatoid arthritis vonatkozásában hiánypótló elemet képez mind epidemiológiai, mind egészségbiztosítási oldalról. Elemzésünk a gyakorlatban segítséget nyújthat az egészségpolitikai döntéshozatalban, illetve a társadalombiztosítási döntések előkészítésében.
Anyagi támogatás: A kézirat az „EFOP-3.6.2-16-201700009: Klinikai kutatások tematikus hálózatának kialakítása és nemzetköziesítése” projekt keretében az „Egészségbiztosítási és klinikai real-world adatvagyon hasznosítása" alprojekt támogatásával készült.

Szerzői munkamegosztás: A vizsgálat tervezése és lefolytatása: El. D., En. D., B. I., Á. I. Adatok gyưjtése és ellenőrzése: El. D., En. D., B. I. Adatfeldolgozás és adatelemzés: El. D., S. A., Cs. T., N. N. Statisztikai elemzések: El. D., Cs. T. Az eredmények értelmezése: El. D., En. D., S. A., Cs. T., N. N., H. L., P. R., K. G., B. I., Á. I. Irodalomkutatás: H. L., P. R., K. G., Á. I. A kézirat megszövegezése: El. D., En. D., S. A., Cs. T., N. N., H. L., P. R., K. G., B. I., Á. I. A cikk végleges változatát valamennyi szerző elolvasta és jóváhagyta.

Érdekeltségek: A szerzőknek nincsenek érdekeltségeik.

\section{Köszönetnyilvánítás}

A szerzők köszönetet mondanak az „EFOP-3.6.2-16-2017-00009: Klinikai kutatások tematikus hálózatának kialakítása és nemzetköziesítése” projekt keretében nyújtott támogatásért (szakmai vezető: prof. dr. Kovács L. Gábor, a Magyar Tudományos Akadémia rendes tagja).

\section{Irodalom}

[1] Scott DL, Wolfe F, Huizinga TW. Rheumatoid arthritis. Lancet 2010; 376: 1094-1108.

[2] Smolen JS, Aletaha D, McInnes IB. Rheumatoid arthritis. Lancet 2016; 388: 2023-2038. [Erratum: Lancet 2016; 388: 1984 .]

[3] World Health Organization. Chronic diseases and health promotion. Chronic rheumatic conditions. Available from: https:// www.who.int/chp/topics/rheumatic/en/ [accessed: September 18, 2020].

[4] Verstappen SM, Bijlsma JW, Verkleij H, et al. Overview of work disability in rheumatoid arthritis patients as observed in crosssectional and longitudinal surveys. Arthritis Rheum. 2004; 51: 488-497.

[5] Anderson G, Horvath J. The growing burden of chronic disease in America. Public Health Rep. 2004; 119: 263-270.

[6] Alamanos Y, Voulgari PV, Drosos AA. Incidence and prevalence of rheumatoid arthritis, based on the 1987 American College of Rheumatology criteria: a systematic review. Semin Arthritis Rheum. 2006; 36: 182-188.

[7] Batko B, Stajszczyk M, Świerkot J, et al. Prevalence and clinical characteristics of rheumatoid arthritis in Poland: a nationwide study. Arch Med Sci. 2019; 15: 134-140.

[8] Cross M, Smith E, Hoy D, et al. The global burden of rheumatoid arthritis: estimates from the Global Burden of Disease 2010 Study. Ann Rheum Dis. 2014; 73: 1316-1322.

[9] Safiri S, Kolahi AA, Hoy D, et al. Global, regional and national burden of rheumatoid arthritis 1990-2017: a systematic analysis of the Global Burden of Disease Study 2017. Ann Rheum Dis. 2019; 78: 1463-1471

[10] Rice DP. Estimating the cost of illness. Am J Public Health Nations Health 1967; 57: 424-440.

[11] Cooper NJ. Economic burden of rheumatoid arthritis: a systematic review. Rheumatology (Oxford) 2000; 39: 28-33.

[12] Michaud K, Messer J, Choi HK, et al. Direct medical costs and their predictors in patients with rheumatoid arthritis: a three-year study of 7,527 patients. Arthritis Rheum. 2003; 48: 2750-2762. 
[13] Singh JA, Saag KG, Bridges SL Jr, et al. 2015 American College of Rheumatology Guideline for the treatment of rheumatoid arthritis. Arthritis Rheumatol. 2016; 68: 1-26.

[14] Taylor PC, Moore A, Vasilescu R, et al. A structured literature review of the burden of illness and unmet needs in patients with rheumatoid arthritis: a current perspective. Rheumatol Int. 2016; 36: 685-695

[15] Brodszky V, Bíró A, Szekanecz Z, et al. Determinants of biological drug survival in rheumatoid arthritis: evidence from a Hungarian rheumatology center over 8 years of retrospective data. Clinicoecon Outcomes Res. 2017; 9: 139-147.

[16] Lundkvist J, Kastäng F, Kobelt G. The burden of rheumatoid arthritis and access to treatment: health burden and costs. Eur J Health Econ. 2008; 8(Suppl 2): S49-S60.

[17] Guillemin F, Durieux S, Daurès JP, et al. Costs of rheumatoid arthritis in France: a multicenter study of 1109 patients managed by hospital-based rheumatologists. J Rheumatol. 2004; 31: 1297-1304.

[18] Kalkan A, Hallert E, Bernfort L, et al. Costs of rheumatoid arthritis during the period 1990-2010: a register-based cost-ofillness study in Sweden. Rheumatology (Oxford) 2014; 53: $153-160$.

[19] Hamuryudan V, Direskeneli H, Ertenli I, et al. Direct and indirect healthcare costs of rheumatoid arthritis patients in Turkey. Clin Exp Rheumatol. 2016; 34: 1033-1037.

[20] Souliotis K, Golna C, Kani C, et al. Real world, big data cost of pharmaceutical treatment for rheumatoid arthritis in Greece. PLoS ONE 2019; 14: e0226287.

[21] Boncz I, Evetovits T, Dózsa Cs, et al. The Hungarian Care Managing Organization Pilot Program. Value Health Reg Issues $2015 ; 7: 27-33$

[22] Varga V, Boncz I, Sebestyén A, et al. Utilization indicators of balneotherapy in Hungary. [A gyógyfürdőellátások igénybevételi mutatói Magyarországon.] Orv Hetil. 2019; 160(Suppl 1): 22 28. [Hungarian]

[23] Boncz I, Vajda R, Ágoston I, et al. Changes in the health status of the population of Central and Eastern European countries between 1990 and 2010. Eur J Health Econ. 2014; 15(Suppl 1): 137-141.

[24] Endrei D, Molics B, Ágoston I. Multicriteria decision analysis in the reimbursement of new medical technologies: real-world experiences from Hungary. Value Health 2014; 17: 487-489.

[25] Boncz I, Sebestyén A. Financial deficits in the health services of the UK and Hungary. Lancet 2006; 368: 917-918.

[26] Eisingerné Balassa B, Csákvári T, Ágoston I. Health insurance pharmaceutical expenditures in Hungary. [Az egészségbiztosítási gyógyszerkiadások alakulása Magyarországon.] Orv Hetil. 2019; 160(Suppl 1): 49-54. [Hungarian]

[27] Boncz I, Nagy J, Sebestyén A, et al. Financing of health care services in Hungary. Eur J Health Econ. 2004; 5: 252-258.

[28] Poór Gy. Ten years of biological therapeutic management of patients with arthritis in Hungary. [Tízéves az arthritisek biológiai terápiás ellátása Magyarországon.] Magy Reumatol. 2015; 56: 199-207. [Hungarian]

[29] Elmer D, Endrei D, Pónusz R, et al. Epidemiological disease burden of rheumatoid arthritis based on routinely collected health insurance claims data. Value Health 2020; 23(Suppl 1): S373-S374.

[30] Boncz I, Endrei D, Pónusz R, et al. Annual health insurance treatment cost of rheumatoid arthritis based on routinely collected financing data. Value Health 2020; 23(Suppl 1): S372.

[31] Orlewska E, Ancuta I, Anic B, et al. Access to biologic treatment for rheumatoid arthritis in Central and Eastern European (CEE) countries. Med Sci Monit. 2011; 17: SRl-SR13.

[32] Péntek M, Poór G, Wiland P, et al. Biological therapy in inflammatory rheumatic diseases: issues in Central and Eastern Euro- pean countries. Eur J Health Econ. 2014; 15(Suppl 1): S35S43.

[33] Lepp-Gazdag A, Gulácsi L, Brandtmüller Á, et al. Prevalence, incidence and therapy of rheumatoid arthritis in Hungary. [A rheumatoid arthritis megbetegedés és az ellátás jellemzői Magyarországon.] Eü Gazd Szle. 2002; 40: 645-657. [Hungarian]

[34] Héjj G. Rheumatology in the light of numbers. [Reumatológia a számok tükrében.] Magy Reumatol. 2008; 49: 70-82. [Hungarian]

[35] Kiss CG, Lövei C, Sütö G, et al. Prevalence of rheumatoid arthritis in the South-Transdanubian region of Hungary based on a representative survey of 10,000 inhabitants. J Rheumatol. 2005; 32: 1688-1690.

[36] Péntek M, Kobelt G, Czirják L, et al. Costs of rheumatoid arthritis in Hungary. J Rheumatol. 2007; 34: 1437-1439.

[37] Péntek M, Szekanecz Z, Czirják L, et al. Impact of disease progression on health status, quality of life and costs in rheumatoid arthritis in Hungary. [A betegségprogresszió hatása az egészségi állapotra, életminőségre és költségekre rheumatoid arthritisben Magyarországon.] Orv Hetil. 2008; 149: 733-741. [Hungarian]

[38] Minier T, Péntek M, Brodszky V, et al. Cost-of-illness of patients with systemic sclerosis in a tertiary care centre. Rheumatology (Oxford) 2010; 49: 1920-1928.

[39] Brodszky V, Bálint P, Géher P, et al. Disease burden of psoriatic arthritis compared to rheumatoid arthritis, Hungarian experiment. Rheumatol Int. 2009; 30: 199-205.

[40] Balogh O, Brodszky V, Gulácsi L, et al. Cost-of-illness in patients with moderate to severe psoriasis: a cross-sectional survey in Hungarian dermatological centres. Eur J Health Econ. 2014; 15(Suppl 1): S101-S109.

[41] Péter I, Elmer D, Endrei D, et al. Annual health insurance disease burden of psoriasis in Hungary. [A psoriasis okozta éves egészségbiztositási betegségteher Magyarországon.] Sport- és Egészségtudományi Füzetek 2020; 4(4): 3-12. [Hungarian]

[42] Rencz F, Brodszky V, Péntek M, et al. Disease burden of psoriasis associated with psoriatic arthritis in Hungary. [Arthritis psoriaticával társuló középsúlyos és súlyos psoriasis betegségterhe Magyarországon.] Orv Hetil. 2014; 155: 1913-1921. [Hungarian]

[43] Mian A, Ibrahim F, Scott DL. A systematic review of guidelines for managing rheumatoid arthritis. BMC Rheumatol. 2019; 3: 42 .

[44] Professional guideline of the Ministry of Human Resources for the domestic treatment of rheumatoid arthritis with synthetic and biological disease-modifying drugs based on the EULAR 2016 recommendation. [Az Emberi Erőforrások Minisztériuma szakmai irányelve a rheumatoid arthritis szintetikus és biológiai betegségmódosító gyógyszerekkel történő hazai kezelése az EULAR 2016-os ajánlása alapján.] Egészségügyi Közlöny 2018; LXVIII(8): 991-1011. [Hungarian]

[45] Belicza É, Takács E, Boncz I. Development of an indicator system for evaluating the quality of health care services. [Indikátorrendszer kialakítása az egészségügyi szolgáltatások értékelésére.] Orv Hetil. 2004; 145: 1567-1572. [Hungarian]

[46] Belicza É, Takács E, Boncz I, et al. Using administrative data for quality indicators of AMI hospital care in Hungary. Value Health 2007; 10: A408-A409

[47] Boncz I, Kovács LG, Ertl T, et al. Health-economic analysis of diseases related to disturbed neonatal adaptation: a cost of illness study. [Újszülöttkori adaptációs zavarokhoz kapcsolódó kórképek egészség-gazdaságtani elemzése: betegségteher-vizsgálat.] Lege Artis Med. 2013; 23: 193-197. [Hungarian]

(Elmer Diána,

Pécs, Vörösmarty u. 3., 7621 e-mail: diana.elmer@etk.pte.hu)

A cikk a Creative Commons Attribution 4.0 International License (https://creativecommons.org/licenses/by/4.0/) feltételei szerint publikált Open Access közlemény. (SID_1) 